\title{
Mapping of Local Media in Aceh; Presence, Challenge, and its Local Political Relation
}

\author{
Nellis Mardhiah, M. Sc, Saiful Asra, M. Soc. Sc \\ State Administrastion Science \\ Teuku Umar University
}

\begin{abstract}
In the context of Aceh, Particularly post-enactment of the Law on Governing Aceh. The presence of local media is not only a part of the vortex of information, but also present as part of local political democratization. This is the challenge of the media or the local press itself. Do the media capable of maintaining its independence in managing information or actually engaging in political practices in favor of certain political groups. This research aims to see local media mapping in post Aceh, the accompanying economic-political dynamics, and a growing press system in Aceh. The underlying argument is that the post-New Order context and the Helsinksi MoU provide wider opportunities for the development of the local press industry, as the growth and inclusion of capital into the region and the emergence of local post-decentralized political actors.
\end{abstract}

Keywords: Local Media, Local Politic, Aceh

\section{INTRODUCTION}

The presence of local newspapers can be an indicator of the dynamics of local life. Various activities of social institutions in public life will appear in the local media. Automatic citizens will need local media. The problem is, are the dynamics of local communities moving after the Autonomy Era? If people's minds are still dominated by central events, while public life at the local level is not dynamic enough in its autonomy, the presence of local media has not become a direct necessity for citizens.

From here it can be understood the main function of press media, namely to provide information for individuals who are actually located in various social institutions. Often called, the press media is present as a social institution, therefore attached to the functions that must be executed in public life. Existence in social life makes the media manager as a social actor who must perform its function in accordance with expectations (expectation) from the community. This hope is the driving force in formatting imperative functions that must be run by the mass media as a social institution. It can be a psychological encouragement of the audience, but equally important is the sociological impulse. If the first impulse brings one to the inner world of a subjective nature, then the second impulse leads one to the outwardly objective empirical world. Press media will supply its people to enter the world it chooses. Such a fictional material of music will bring its users to a subjective world, while factual material such as news is used as a basis for entering the empirical social world.

One's choice of information is determined by its position in the social structure. As for information forever has a pragmatic function for its users. Someone who has a role in the social structure hypothetically can be imagined will need more factual information material. Because with this factual information he puts himself in social interaction. On the contrary, the less one plays a role in social life, by itself it does not necessarily require factual information. This may explain why entertainment information is more interested in the middle of an elitist society structure, due to the limited number of people who have a social role. In other words, the limited use of factual information can be an indicator of the limited role of citizens in public life. Thus the scale of the social life with the role of citizens in it will determine the type of information that is relevant to him.

In the context of Aceh particularly postenactment of the Law on Governing Aceh. The presence of local media is not only a part of the vortex of information but also present as part of local political democratization. This is the challenge of the media or the local press itself. Is the media capable of maintaining its independence in managing information or actually engaging in political practices in favor of certain political groups?

Theoretically, the media and politics can not be separated. Media and politics are like two sides of the same coin in which each one requires 
another. This is what happened in Aceh. Media and political links are highly visible in the practice of the press in Aceh. The presence of the media in Aceh seems very much to serve the political ambition through the news. Such a practice is exactly the conclusion of Ignatius Haryanto (2011) when looking at the local press after ten years of Reformation:

"It is a common practice where mass media in different regions can not operate as a healthy, unprofessional enterprise, and show a great dependence on the dynamics of local politics (from newspaper subscriptions by government offices, congratulatory ads to officials, to various other forms of bribes. "

The practice of the press industry looks like it is thick with the nuances of interest, which is interestingly studied with the approach of political economy. Political economy theorists see that there are certain groups that control economic institutions that then affect other social institutions, including the media and the press. In other words, the mastery of economic institutions will lead to the mastery of almost all aspects of life, ranging from small things such as how to eat too big things like communication devices. The mastery is meant to perpetuate their economic power.

Although such a strong practice of interest is prevalent in the local press industry in Indonesia, according to Haryanto (2011), "it is not easy for people to know" what actually happened on the contrary. Of course, researchers and scholars should look at the phenomenon further. Unfortunately, not many researchers do. The reality is that there is a double academic void here. First, the study of the local press itself can be called minimal. Haryanto (2011) referred to it as "no data". Research is mostly done on the "national press" (Hill \&Sen, 2007), which is ironic in the midst of the phenomenon of the local press industry or the regional press (Robinson, 2008)

Second, the study of political economy to fade the various interests that linger behind a policy long absent in the academic world in Indonesia. The reason, according to Vedy $\mathrm{R}$. Hadiz, the power of the New Order for more than 32 years forbade the analysis of capitalism and class with the scalpel of Marxism, whereas this latter analysis is the basis of the theory of political economy. Any analysis, when using the approach, was immediately regarded as Left by the New Order. Ironically, at that time the power of capital is growing in Indonesia (Robinson,
2008) which immediately trigger the Indonesian scholars to analyze it. As a result, with few exceptions, what came later were analyzes called Hadiz (2002) as "most banal forms and narrow behaviorism".

Based on the above background, this research would like to answer how the map/landscape of local media in Aceh covering the presence, challenge, and relation with local politics in Aceh? This research uses qualitative data as primary data and also did not close the possibility of secondary data also used in this research. In addition, this research seeks to see the mapping of local media in post-New Order Aceh, the accompanying economic-political dynamics, and the growing press system in Aceh. The underlying argument is that the post-New Order context and the Helsinki MoU provide wider opportunities for the development of the local press industry, along with the growth and inclusion of capital into the region and the emergence of local post-decentralized political actors. Therefore, a political economy analysis is important to be used as an analytical blade in this study, whose results will be used to look at the growing press system in Aceh.

\section{LITERATURE REVIEW}

\section{A.Local Media: Positive or Negative Role?}

Calling and defining local media in the present is problematic. In Understanding the Local Media, Meryl Alridge (2007) mentions the problem is mainly related to the realities of today's increasingly global world, characterized by the findings of modern technology that overcomes the barriers of distance that previously became the separator. Globalization that enables real-time social interaction between world citizens, which further refines the global village idea of Marshall McLuhan, in turn transforming the human culture to not only think but also act globally. And the media, as a means of mass communication, Aldridge, is the most important player that drives globalization (2007: $\mathrm{p}$ 7-8). With its global nature, how then might there be a so-called local media?

Apparently, according to Aldridge, in the midst of a wave of globalization, the desire for locality is also strong. Besides being influenced by various global factors, the so-called reality of today can not be shaped by immediate locality. In the definition of globalization, for example, Giddens emphasizes the importance of local involvement in the formation of an event, as well 
as of course the interaction across a distance which is a global contribution. The longing for the locality, according to Aldridge, led to the preference of the British public, the country he studied, of the media that raised the local news very strongly (Ashadi, 2002).

Local coverage or orientation, in the view of AshadiSiregar, is one measure to see if a medium can be called local media or not, in addition to circulation. Siregar made three "tiers" of media based on the orientation and circulation, which are the "tiers" of both: local, regional, and national. According to Siregar, "the national encompasses all regions of the country; regional areas covering part of the national territory, inter-regional nature; while locally covering a city or a limited area. "With such a framework, there is a possibility that a media, for example, is locally oriented but is nationally circulated or otherwise regionally oriented but its circulation is local only. The so-called local media, in Siregar's view, is, in reality, a locally oriented and circular region as well local.

Siregar's definition must have been very loose when compared to the definition of Bob Franklin (2006) requiring local media "locally owned, locally produced, employing local journalists, reporting local concerns, and being read by local people." If Siregar only emphasizes news and territory orientation, Franklin added that owners, producers, and media workers must also be local. Despite strict definitions, Franklin was pessimistic that all the local requirements could be met. Franklin himself mentioned, in the present, what is called the local media just name. Local media owners are often media groups that not only have media in an area but also in other regions, even industrial groups from other countries. With such ownership, production can be located far away and editorial decisions are determined from other regions. The most worrying thing, as a consequence, is the breaking of the relationship between the community of a region and the media circulating there. Similar to Franklin's opinion, the relationship of both is also very important for Siregar. The two are called Siregar as orientation and circulation, which actually show two functions or the role of media: as social institutions and business institutions. Siregar said,

As a social institution, [media] is outward looking for the benefit of society. As a business institution, the mass media is the same as any corporation, which runs its operations with an inward-looking, for its own sake.

The two roles are in fact difficult as they go along and often become a dilemma in journalistic work, including for local media. In the context of Indonesia, the remarkable growth of local media post-Reformation (Sutrisno, 2009) is not only due to the elimination of SIUP as a condition of media publishing, but also the fruit of local dynamics following decentralization policies. Changes in the political landscape of Indonesia that make the district and city as the basis of autonomy, in turn, require a common public space that serves to generate community imagination and ideals of identity. In the history of modern Indonesia, the media is considered capable of fulfilling the task (Anderson, 2009) As a result, although it is a business institution, local media actually do not forget its duty as a social institution. The two roles should go hand in hand. The question is, whether the local media has done both tasks?

Although the local media thrives in the post-New Order era, strangely, research is not done much. In his reflection after a decade of Reformation, Haryanto (2011) mentions "no data" about the local media. Haryanto is obviously overwhelming with that conclusion, because in fact, although it can be said little, some research on local media has been done. In general, such research can be grouped into two: the role of the local media is considered positive and the role is negatively perceived.

Research Tessa Piper (2009) for example see the role played by the media is positive, namely strengthening the role of civil society in conducting oversight of local government and run empowerment work. Local media also rekindle the hope of growing democratic communications within the community.

Meanwhile, research by Eriyanto (2008), David T. Hill (2011), and Birgit Brauchler (2011) see the role of local media as negative. These local media confuse the conflict, not reconcile, and apply the clientelist in the arena of local political contestation. The negative role was taken by the media with the aim of taking as much profit or profit as possible to raise the institution. They proved that the development of the local media industry in the post-New Order era was supported by undue media behavior, where it met many interests. The local media industry in a region, therefore, needs a study that is not just a conventional economy, but an 
analysis capable of seeing the gap between the various interests.

\section{B.Political Economy and the Spreading of Capital}

One of the analyzes that capture the various interests behind a social fact or event is the political economy. Initially, this analysis is a critique of conventional economic analysis that emphasizes equilibrium. Adam Smith, the originator of the classical economic theory, argues that the ownership of money or capital will spread by itself through a purely market mechanism based on the principle of exchange. With this principle, grasping all the money and removing all the goods will only make the price fall, instead taking all the goods and releasing the money will make it rise. These two extreme angles are unlikely to happen and money will naturally spread, ultimately creating a balance between the ownership of money and goods. One critique of this classical economy is its neglect of various factors outside the economy such as social structure, access to information, and so on. In other words, the economy does not consider the power relations that want to control the market and production as well. As a critique of conventional economics, therefore, political economy is defined as "social relations, especially power relations, which form the production, distribution, and consumption of resources" (Mosco, 2009). Communication certainly does not differ from and including those resources, so communication products such as newspapers and their distribution and consumer choice are also shaped and influenced by power relations. With its emphasis on power relations, political economy is heavily contributed by the Marxist tradition.

According to Vincent Mosco (2009), there are four characteristics of political economy analysis, namely historical, multidisciplinary, moral emphasis, and praxis. A brief explanation of the four is that the forces that constitute a social fact can not simply be understood in a certain period of time, so it needs to be seen in a long span of history. Similarly, a social fact is not enough to be seen from a single angle or theory, but rather the use of many theories. The assumption is that social facts are complex and total. Unlike other "normal" analyzes for the sake of science, political economics focuses on disproportionate social relationships that harm the public, whose outcome is not simply a reflection, but practical and usable or useful to the public.
With its historical and multidisciplinary characteristics, approaches in political economy have become very widespread. Mosco (2009) itself suggests three entrances, namely commodification, spatialization, and structure. In essence, all three see power relationships that shape changes in the value and function of resources (commodification), affect the dynamics of space in which resources are located (spatialization), and regulate the social practice of a resource (structure).

In Indonesia, the analysis of political economy did not develop much especially during the New Order period. The reason, according to Vedi R. Hadiz, New Order politics is always upset with Left discourse and think of it as a threat. Following Hadiz's (2013) uproar over the policy and his hopes after the New Order collapsed:

"The absence of serious Indonesian political economy studies by the Indonesians, I argue, is due to the New Order's marginalized politics of Marxist analysis. Although not all political economic studies are inspired by Marxism-some are anti-Marxists-the twin themes of capitalism and class are generally considered to belong to Left discourse. Hence, with few exceptions, Indonesians rarely come into contact with issues related to the rise of capitalism in Indonesia. The analysis of Indonesian politics and society then tends toward a very shallow form of narrow behaviorism. The fall of the New Order and the openness of the political space it produced may hopefully give birth to a new study of Indonesian political economy by Indonesians. (Hadiz, in "Studies in the Political Economy"; 2013) "

Although not the first, a work that has had a huge influence on the study of political economy in Indonesia, even in Southeast Asia, is Indonesia: The Rise of Capital by Australian scholar Richard Robison, first published in 1986. Hadiz praised him as a "road pioneer which significantly changed the focus of Southeast Asian and Indonesian studies in the 1980s from behavioral approaches, world systems, and dependence theory to 'economic-political' approaches. "This book essentially addresses the formation of a new capitalist class of Indonesia in conjunction with the improving economy after the long road of colonialism, the old Order and the New Order. The ruler of capital, according to Robison, was not the traditional Muslim bourgeoisie that had been influential in the early twentieth century, but the Chinese businessmen 
and indigenous people who held bureaucratic powers and connected with conglomerates.

One of the works influenced by Robison's book is the dissertation of Daniel Dhakidae (1991) at Cornell University. The title of the dissertation clearly takes the phrase from Robison: "The State, the Rise of Capital, and the Fall of Political Journalism: The Political Economy of Indonesian News Industry". This dissertation shows that the rise of the New Order economy and state interference with the press made the media industry metamorphose from the political press or the press struggle to the Pancasila or development press. This last press eliminates media characters during the Old Order as a tool of political competition to become a media as a business institution to increase capital.

After a change of significance in the political landscape of the fall of the New Order and the entry of Indonesia into the new era of the Reformation, what happened to the class of capital? Together with the student, Vedi R. Hadiz, Robison (2011) points out that there are not many changes related to them. Although the regime changed, the power structure and class influence did not change. Political bureaucrats and entrepreneurs reorganize and consolidate power to then assert themselves as the oligarch.

While also seeing the existence of capital continuity in the New Order and Reformation period, Edward Aspinall holds that there are some quite striking differences and changes. With Chinese entrepreneurs still becoming the most important capital rulers, which are changing now include the strengthening of private and indigenous capital which is the fruit of the New Order's protectionist policy towards bureaucratic families. In addition, the most striking changes related to the decentralization era that became the focus of this research were the emergence of local businessmen as well as the distribution of capital to the regions. This last point, according to Aspinall, brings about the unpleasant effects of regional autonomy: local entrepreneurs compete to be regents or governors or legislators, who further control the budget, and in turn, mutually collude to foster wealth. The practice of corruption in the region, as Aspinall, has never been as vulnerable as the eyes of the Reformation era, involving mainly rulers and bureaucrats as well as entrepreneurs.

Along with the rise of the local capital class and the distribution of capital to the area that the local media industry grew post-New
Order. Except for local entrepreneurs, the press industry in Jakarta and Java then made local media as a subsidiary. In the midst of a strong corruption climate in the region, the local media is feeding itself both as a social and business institution, which in turn forms what is called a media system.

\section{Medium-Term Political Economy and Media Reality}

The attraction of interest between the local media and the political elite in Aceh's 2012 election polemic is possible due to several causes that stem from media professionalism. Media professionalism can be seen from the final product of the media in the form of content or text, which is simply visible from the news presented about the polemic of the election which is shown less balanced. It further refers to the dynamics of socio-cultural, political economy, historical context, and media regulation. In the process of politics and democracy, mass media is a medium that has a significant level of influence. The political economy approach focuses on a major study of the relationship between the economic-political structure, the dynamics of the media, and the media ideology itself, leading to the ownership, control and operational power of the media market. Media production is determined by a variety of conditions of market expansion pressure and also determined the economic and political interests of capital owners and media policymakers. Where these interests are related to the need for profit, as a result of monopolistic tendencies and integration processes, both vertically and horizontally.

In the perspective of the critical political economy, the extensification of media domination is controlled through the dominance of the production of media content in line with the preferences of the capital owners. The commodification process of the mass media shows the dominance of the role of market forces.

Base (2009) in Henry Subiakto and Rachmah Ida, writes that the roots of the political economy of the media stem from the views and conceptions born of cultural studies experts such as Theodore Adorno, Richard Hoggart, Raymond William, and E.P. Thompson introduced the theory of 'cultural materialism'. Explain that culture has become a commodity produced with a particular interest in the maker for the benefit of financial gain. 
In the ownership of the mass media, Peter Golding and Graham Murdock (2000) in Henry Subiakto and Rachmah Ida, argue that mass media is a cultural producer who is more of a role as a profit-seeking business machine. Where the ideology of capitalism has permeated in the media institutions and coloring the relationship between the owner and his workers. Although the text and the content of the news by the media do not show its support for capitalism, it basically refers to serving the interests of the market. The media company as a capitalist institution, its business has reached everywhere, but the control of ownership is centered on a few people.

In view of that opinion, if we look into the discourse of any content of the emerging media, whether in the form of text, conversation, or anything, it is not seen as natural, fair and objective or neutral, but a form of a power struggle. The power in question is the control of one person or group controlling another person or group through the discourse that has been constructed and framed. A person who has more power and dominance has the power not only in determining which parts need to be displayed and which man is not, but also how it should be displayed. For example can be seen from the repetition of news, protrusion of reality or the use of certain words.

As the media business began to be managed by the investors, the ruling elites and entrepreneurs collaborated on organizing the media content. So the freedom of the press or journalists has been infiltrated by propagandapropaganda of the interests of a handful of people. Every news has been constructed by investors with political and business power.

Chomsky (2000) considers that there is a conspiracy of the elite in control of constructing reality into news and information. He sees the media as a tool of political, economic, military, and cultural interests of the authorities. According to him, the gate keeper media has become a pawn of politicians and investors to seek profit. In other words, in the name of politics or nation, the rulers organize every news according to their desires and interests.

The political realities of the present, greatly hunted by the media. Politics has always been the main topic (trending topic) of news in the mainstream media. In fact, a crisp conversation of the community in some social media. Almost every day, there are always politicians who appear on television and radio as speakers of political talk shows, in-depth interviews in newspapers and magazines, to exist personally on various social accounts. The common reality that politicians are turning to the media, with their diligent follow-up to politics, automatically gives politicians a major role in the media's political stage.

Turning the political stage from the region of representation to the broader public space of the media, making the politicians aware of their appearance. Performance that is served is no longer only the quality of politics but also the art of appearance and role art. After all, media is the stage, so every politician who performs must master the "art of staging". When politicians enter the media, they are paid and the media also get advertisements. In the end, what is feared is that existence is no longer measured from its work but how often it appears in the media, which of course is detrimental at the same time sacrificing the rights of public politics.

But be aware that the role of politicians in the media is not like celebrities who play a different character. They must appear maximally when showing actual political responsibility and not present imaginary political things. Different roles of politicians lie in political framing, building issues, composing discourses, and developing political meaning for the public. It becomes an important capital for politicians in realizing and defining the political situation occurring in the media.

Erving Goffman's opinion (in Eriyanto, 2002), on the definition of a situation, can be differentiated into strips and frames. The strip is an activity sequence, whereas the frame is the basic setting pattern used to define strips. Politicians' understanding of the political strip becomes important so that role-by-role does not deviate from the rundown of media politics. When appearing, politicians and the media both play an important role in educating the public about the political situation that occurs, so the political sequences that will be discussed must be mastered. According to Siti Aminah in her journal, Media politics is a political system, the term is to compare with other systems, such as legislative politics, bureaucratic politics, judicial politics, and party politics. Within each of these domains, identifiable key roles, multiple interests, routine rules of conduct, and established interaction politics, which can combine to clarify the particular form of politics. 
Aminah added that there are 3 (three) actors in media politics, namely; politicians, journalists, and people who are driven by special interests. For politicians, the purpose of media politics is to be able to use the mass community in mobilizing the public support they need to win elections and play programs while sitting in the workplace. For journalists, the political objective of the media is to create a writing that draws the attention of audiences and emphasizes the socalled "independent and significant voice of journalists". As for society, the purpose for the purpose of monitoring the politics and keeping politicians accountable, using a minimal business base.

C.Gramsci and the Power of Hegemony in Controlling the Media

In the first case of hegemony, it is very difficult to define it. This seems difficult to answer when we talk about Gramsci, because, at least in The Prison Notebooks, he never gives a precise definition of the term. This may be the main reason why there is so much inconsistency in the literature of hegemony, people tend to form their own definition, based on their own reading of Gramsci and other sources. The problem here is that if someone reads Gramsci in half, then their definition is like that.

For example, Martin Clark defines hegemony as "the way the ruling class controls media and education". Although this definition may be narrower than usual, it reflects the usual error-reading of the concept, namely that hegemony is the way the ruling class controls the institutions that control or influence our thinking. However, much of the academic and activist hegemonic literature takes a slightly wider perspective than this, by including more institutions in the hegemony of engagement - at least involving the military and the political system. The problem is that even when these institutions are taken into account, the focus tends to be exclusive to the ruling class, and the methods of control. Hegemony is often used to describe the way capitalist classes infiltrate people's minds and apply their dominance. What Gramsci is missing does not only use the term "hegemony" to describe the activities of the ruling class, it also uses it to describe the effects of progressive forces. With this in mind, we can see that hegemony should be defined as being done not only by the ruling class, in fact, it is the process by which social groups (whether they are progressive, regressive, reformist, etc.) gain the power to lead, how they expand their power and defend it.

To understand what Gramsci is trying to achieve when developing his hegemonic theory, we need to look at the historical context he faced and the debate in the movement of the time. The term "hegemony" has been commonly used by socialist circles since the early 20th century. Its use shows that when a group is described as "hegemonic" then it occupies a leadership position within a certain political sphere. The use of the term hegemony (the Russian term for hegemony, often translated as a vanguard) by Lenin seems to imply a process more akin to what Gramsci describes. In attempting to catalyze the Russian Revolution, Lenin made the observation that when allowed to take care of itself, the workers tend to attain only the consciousness of the unions, fighting for a better state in the existing system. To bring about revolutionary change, he argued that the Bolsheviks needed to occupy a hegemonic position in the struggle against the tsarist regime. This means not only empowering the various unions by uniting them, but also involving all the "opposition strata" in society into the movement, drawing relationships between all forms of "political oppression and autocratic authority".

However, in the post-revolutionary period, the implications changed. Lenin argued that it was crucial to establish the "hegemony of the proletariat". the hegemony of the proletariat is first, the urban proletariat maintains its alliance with rural peasants (who are the majority of Russians) to maintain national leadership and second is the old capitalist skill in use, by forcing them to effectively manage the state industries. Both of these leadership processes are done via consensus and the use of coercion in the development of hegemony will play a crucial role in Gramsci's theory. From 1922 to 1923 Gramsci was in Russia when these debates were on the rise and after this period we saw hegemony begin to occupy a central role in his writings.

Despite the influence caused by the events in Russia, Gramsci was also influenced by his own political experience. Gramsci was deeply involved in the struggle against capitalism and fascism in Italy and for some time he was the leader of the Italian Communist Party. In the period after World War I, there was great optimism in Europe, and especially in Italy, because at that time the people saw the 
oppression of the ruling classes, while in Russia an alternative was developing, so that a kind of worker revolution in Europe began looks on the surface.

Gramsci certainly believes in this optimism. Events that took place in the early 1920s seemed to confirm this. The tension in all strata of society is high, there is mass agitation and the people form factory councils and worker cooperatives. But apart from this intense mobilization, it all goes off immediately. Cooperative unions are coopted, workers' cooperatives become marginalized and uncompetitive. The common people are intimidated by the elite or fascinated by the appeal of fascist rhetoric.

As explained above, in The Prison Notebooks Gramsci refers to hegemony to describe the activity of the dominant group as well as the progressive forces. For Gramsci, no matter what social group, we can see that there are certain stages of development they must pass before they can become hegemonic. Taking from Marx, the first requirement is the economy: that material forces have developed enough that the people within them are able to solve the most pressing social problems. Gramsci then goes on to state that there are three levels of political development that a social group must go through in order to develop a movement that can initiate change.

The first stage of this is called "corporateeconomics". A corporatist is probably what we understand as an individual who puts his own interests first. Someone affiliated with the corporate-economic stage as a function of his personal interests, realizing that they need the support of others to gain their own security. Unions may be the clearest example for this, at least in cases where people join unions for fear of cut-off pay, and depreciation. In this term, we can also enter the short-run cooperation between capitalist-capitalists who actually compete with each other. The point is emphasized: at this stage of historical development, the group concerned does not have a sense of solidarity among its members.

In the second stage, group members begin to realize that there is a wider interest area and that there are others who share their interests and will continue to share these interests in an affordable future. It is at this stage that a sense of solidarity develops, but this solidarity is still only based on mutual economic interests. There is no shared world view or anything like that. Such solidarity can lead to efforts to promote reforms in the legal field to improve the group's position within the existing system, but there has been no awareness of how they, and others, can benefit from the establishment of a new system.

Just by passing through the third stage then hegemony can really become possible. At this stage, members of social groups begin to realize the importance and need to reach beyond what they can do in the context of their own classes. What is needed is for their interests to be carried by other subordinated groups just as they do. This is what Lenin and the Bolsheviks think about in forming an alliance with the peasants that just by making the Bolshevik revolution also a peasant revolution, where the peasants also see it as their revolution, the urban proletariat can maintain its leadership position.

Gramsci understands that in the historical context he is working on, the passage of a social group from reformism to self-interest to national hegemony can occur effectively via political parties. In this complex formulation, the various ideologies of the allied groups will come together. Inevitably there will be conflicts between these ideologies, and through the process of debate and fighting, an ideology, or a combination of unity thereof, will appear to represent the allied classes. This ideology is arguably hegemonic, the group representing it has achieved a hegemonic position over subordinated groups. At this stage, the party reaches maturity by achieving unity between economic and political goals as well as a moral and intellectual unity - it can be said as sharing a world view.

With this unity behind it, the party transforms society to lay down the requirements for the expansion of the hegemonic group. The state becomes the mechanism for doing this: policies are generated and enforced to enable the hegemonic group to reach its goals effectively and create symmetry between its goals and the goals of other groups. Although these objectives are formulated with the idea of advancing the interests of one group, they must be experienced by the population in the interest of all. For this to be effective, the hegemonic group must have a certain form of dealing with the interests of the subordinated classes. Dominant interests can not simply be applied to them.

Although Gramsci considers these pragmatic steps required by each group seeking to gain power, it also has a deeply ethical concern 
about how the process works. In this sense, we can find in Gramsci's the qualitative distinction between the exercise of hegemony by regressive and authoritarian groups on the one hand and social groups on the other. At the ethical level, Gramsci is above all an anti-dogmatic believer who believes that righteousness can not be applied from top to bottom, but only through concrete and sympathetic dialogue with the people. If regressive hegemony involves the adoption of a set of non-negotiated values to the masses, especially through coercion and deception, progressive hegemony will develop with the consensus of a democratically attained society.

Clearly, if we trace history, the capitalist class holds its hegemony primarily through coercion, ranging from direct military placement to finer forms, for example, using economic power to remove political opponents. However, it is a big mistake to think that capitalism is not dependent on building consent or consensus. It can even be argued that capitalist developments that from a strategic point of view we need to pay more attention to because at this level we are competing with them. The nature and power of this consensus vary. There are ways in which successful capitalism actively sells its vision to subordinated classes. This does not mean simply selling a distorted vision of a free, independent, innovative society but also using bourgeois economic ideas to convince the working class to believe that, for example, even though the capitalist policy is in the capitalist interests of the capitalist class, the effects of trickle-down effects. Capitalism can also win approval or consensus among those who may not believe that the existing system is for their benefit, but believes that there is no alternative or that alternatives will be worse - in other words, by promoting the belief that the existing system is a necessity needed ( a necessary evil).

The 20th century witnessed capitalism massively expanding this form of consensus, primarily through the control of corporations in media and advertising. In the United States, in particular, the promotion of the American dream, and all the useless commodities needed to achieve it is not only useful for boosting consumption and at the same time benefiting the economic interests of the capitalists; it also sells a lifestyle that capitalism can only provide. This was certainly helped during the Cold War with simultaneous attempts to brand each alternative to capitalism as slavery. The capitalist class opposes any policy that seeks to rival the corporate-owned media by using its hegemonic political power to create conditions for further consensus development, which will then broaden their interests. The hegemonic group will continue to struggle in these ways to reach a greater level of consensus - in this case by locking people into a rigid thinking and crushing each optimism.

Certain forms of unionism can also be an example of capitalist hegemony. What Gramsci calls "syndicalism" (the view that the conditions of the working class can be maximally raised by increasing the strength of trade unions) reflects a social group (workers) mired in the stage of corporate-economic development due to the capitalist hegemonic influence, especially the defenders of free trade (free trade), in the realm of ideology. The advocates of free trade argue that the state and civil society must remain separate, that the state must come out of the economic sphere, which functions autonomously - submit it to the "invisible market hands" and so on.

The syndicalists adopt the assumption of the separation between the social and economic realms on the one hand and the political sphere on the other and assume that they can bring about radical change without political representation. The concrete result of this is that they can only negotiate for narrow-minded improvements in the economic sphere, without a policy change that allows these victories to reach a more permanent basis. While the advocates of free trade are actively involved in the determination of policies (despite their claims to say otherwise) that create conditions favoring the capitalist class.

However, when the interests of the capitalist class are directly threatened, the hegemonic power inevitably turns to coercion. There is no more space to negotiate this, in the existing hegemonic order. At a modest level, this could mean making legislation allowing police to attack workers who carry out industrial actions, which threaten direct profits but the greatest threat to capitalists is the development of hegemonic alternatives in civil society. The threat is that the people will shift from the corporateeconomic phase and realize that their interests intersect with all those who are marginalized by capitalism and fight back, that they will realize their power and demand radical change because it is the greatest threat to capital, the most 
effective way for it to use coercion is to divide progressive alliances between subordinated groups. When confronted with violence and economic threats, people are less able to associate themselves with groups. Concerns for survival mean that everyone has to defend their interests individually. The progressive hegemony of the movement becomes impeded because each person is forced to act operatically. The ruling class can also attempt to roughly divide the movement by heating up ideological differences, for example by calling on religion.

Gramsci considers that the development of progressive hegemony involves more openness, democracy, and consensus, than coercion. If there is any coercion, it should be there to counter the reactionary forces that are trying to impede the development of society. This will give space to the masses to reach their potential. The big part of The Prison Notebooks is given to find out what it takes to develop this kind of hegemony, and many Gramscian thinkers have since dedicated themselves to answering this puzzle.

For starters, we can say that the existing hegemony tries to keep the disillusioned and disenfranchised groups scattered, the progressive hegemony that is about to rise should unite them. Gramsci certainly saw the challenges that are here. In its own historical situation (and undoubtedly still in our day) there are considerable obstacles between marginalized groups in terms of experience, language and worldview. However, what these groups all share is that none of them has adequate political representation in the existing system. Gramsci calls these groups that have no political representation "subaltern". The challenge of the hegemonic group is to critique the existing system in such a way that the subaltern groups are aware of their fate and then "rise" into the political life of the party. To facilitate this integration by others, Gramsci emphasized the need for hegemonic groups to move beyond their own corporatist-economic understanding of interests, sacrificing some urgent economic objectives for a deeper moral and intellectual unity. He must abandon his traditional prejudices and dogmas and take a broader view if he wants to lead while gaining trust and consensus (both are needed to defeat the existing powers).

If this in line force is to have important historical influences, they must be lasting and organically / united in relation to conditions on the ground, not merely a moment of convergence. To develop the momentum of the masses, they must demonstrate, both in the people's imagination and in action, that they are able to gain power and carry out their own tasks. These tasks must effectively be the task of everyone they must represent each aspiration, and be the fulfillment of the tasks of the unsuccessful movements of the previous generation.

Based on Gramsci's hegemony theory, power is part of the hegemonic process. Thus, power is defined as the condition of a person's or group's ability to influence the behavior of others or groups in accordance with the wishes of the authorities and to achieve that power is needed strategies to maintain and preserve power. In fact, by linking violence through militarism.

Media basically has the function and role to convey information to the public. Its position is so strategic in society. In fact, the media is able to form a new social structure and social order. One is local media that can accommodate the needs of large and complex communities on the one hand but at the same time anomi.

For the ruler, the media is the most appropriate tool to lead society to the obedience and interests of the authorities. Media can be used as a propaganda tool. Thus, it is not surprising that political interest cooperation often occurs between the political elite and the media ownership organization. Collaboration is to build the structure of society as they wish in order to perpetuate power. Seeing such conditions, Gramsci assess the mass media is a hegemonic device of the ruler. In a democratic country, mass media participates in the determination of political power policy. In the election in Aceh, for example, there has been a collaboration between the organizers of political power with one of the local media. In addition, the mass media is even a supporter of a political party or candidate for political power. The message presented tends to foster a positive image of the party or candidate program. Thus it is difficult to see the position of media neutrality. He can not be separated from the interests of the ruler or any businessman. The media, with texts, images, and various other symbols later became the terror that infiltrated the human consciousness. It can be a form of good terror, enlightening, and educating. Conversely, mass media can also be a nightmare. Become a terror of consciousness, then herd our awareness of what the media wants. 
Regardless of the pros and cons, cultivation theory suggests that reality in the media is considered a true reality. Where the events presented by the media is considered as a representation of the real situation in society. Seen in the Aceh 2012 election, Aceh local media (Serambi Indonesia and Modus Aceh) reported the condition of the election of Aceh that is not conducive to polemic. In fact, the news is contrary to the real conditions. Media seems to make hyper-reality, exaggerating reality by raising the scale of the issue. Thus, who controls mass media messages can also control public opinion. Who controls public opinion he will have power.

\section{BIBLIOGRAPHY}

Abar, Akhmad Zaini, Kisah Pers Indonesia ,19661974, (Yogyakarta: LKiS, 1995). Alridge, Meryl, Understanding the Local Media, (Berkshire \& New York: McGraw-Hill \& Open University Press, 2007).

Anderson, Benedict R. O'G. ,Imagined Communities: Reflections on the Origin and Spread of Nationalism, (London: Verso,1983).

Aspinall, Edward, "Kemenangan Modal? Politik Kelas dan Demokratisasi Indonesia", Prisma, 32 ,1 (2013).

Blumler, Jay G., Jack M. McLeod, Karl Erik Rosengren (eds.), Comparatively Speaking: Communication and Culture Across Space and Time, (California: Sage Publications, 1992).

Brauchler, Birgit, "TheTransformation of Media Scene: From Warto Peace in the Moluccas, Eastern Indonesia", Kishna Sen \& David T. Hill (eds.), Politics and the Mediain TwentyFirst Century Indonesia: Decade of Democracy, (London \& New $\quad$ York: Routledge, 2011): 119-40.

Burhanuddin\&Jamaluddin,“OutofFrame:StudiPe mberitaanPemilukadaProvinsiJambi 2010 $n,(2010)$. olehMediaLokaldiJambi",laporanpenelitia

Dhakidae,Daniel,"TheState,theRiseofCapitalandt heFallofPoliticalJournalism: PoliticalEconomy ofIndonesianNewsIndustry", disertasidiCornell University, (1991).

Durham\&DouglasM.Kellner(eds.),MediaandCultu ralStudies:KeyWorks, (USA: Blackwell,2006).
Eriyanto, "Koran, Bisnis, danPerang", Andreas Harsono\&Budi Setiyono(eds.), JurnalismeSastrawi:AntologiLiputanMend alamdanMemikat,(2008):203-232.

Eriyanto,Mediadan

KonflikAmbon:Media,Berita,danKerusuhan Komunaldi Ambon,1999-

2002,(Jakarta:KantorBeritaRadio68H,200

$3)$.

Franklin,Bob,"LocalJournalismandLocalMedia:C ontestedPerceptions, Rocket Scienceand ParallelUniverses", BobFranklin

(ed.),Local JournalismandLocal Media: Makingthe LocalNews,(London\&New York:Routledge,2006).

Hadiz,VediR.,"Komoditas,Modal,danWajahEkono mi-PolitikBangsa",Prisma,32,1,

(2013).

Hadiz,VediR.,"StudiesinthePoliticalEconomyofNe wOrderIndonesia",Kyoto Review of SoutheastAsia,1(2002).

Hallin,DanielC.\&PaoloMancini,Comparing MediaSystem:ThreeModelsofMedia and Politics,(Cambridge\&NewYork:Cambridg eUniversityPress,2004).

Haryanto,Ignatius,"MenilikPersLokal10TahunSet elahReformasi",JurnalDewan Pers, 5(2011).

Hill,DavidT.\&KrishnaSen,TheInternetinIndonesia' sNewDemocracy, (London\& New York: Routledge,2007).

Hill, DavidT., "Mediaand Politicsin Regional Indonesia:The Case of Manado", KrishnaSen\&TerenceLee(eds.),PoliticalR egimes and theMedia in Asia, (London\&NewYork: Routledge,2008):188-207.

Hill,DavidT., "Onthe Border:LocalMediain the Landof Papua",KishnaSen\&David T.

Hill

(eds.),PoliticsandtheMediainTwenty-

FirstCenturyIndonesia:Decade of e,2011):26-48.

Democracy,(London\&NewYork:Routledg

Ida,Rachmah,"Reorganisation

ofMediaPowerinPost-AuthoritarianIndonesia:

Ownership, Power 
andInfluenceofLocalMediaEntrepeneurs" , Krishna Sen\& David T.Hill (eds.),Politicsand theMedia inTwentyFirstCentury Indonesia: Decadeof e,2011): 13-25.

Kuntowijoyo,PenjelasanSejarah,(Yogyakarta:Tiar aWacana,2008).

Lim, Merlyna, @Crossroads:Democratization and Corporatization of Media in Indonesia,(Arizona:ParticipatoryMediaLa b\&FordFoundation,2011).

Lim,Merlyna,TheLeagueofThirteen:MediaConcent rationinIndonesia, (Arizona: ,2012).

ParticipatoryMediaLab\&FordFoundation

McLuhan,Marshall,WarandPeaceinthe

GlobalVillage,(NewYork:Bantam,1968).

Mosco, Vincent, The Political Economy of Communication, 2nd edition, (London, 09). California,NewDelhi,\&Singapore:Sage,20

Nordholt,HenkSchulte\&GerryvanKlinken(eds.),Re negotiatingBoundaries:Local Politicsin KITLV,2007 Post-SoehartoIndonesia,(Leiden:

Obet, "RelasiKapitalismedenganOrganisasiMedia”, www.koranpembebasan.wordpress.com-

/2013/11/13/relasi-kapitalisme- denganorganisasi-

media/,diunduhpada12Desember2014.

Picard,RobertG.,ThePressandtheDeclineofDemocra cy:TheDemocraticSocialist Responsein

PublicPolicy,(Connecticut:

GreenwoodPress,1985).

Piper, Tessa, Keeping Local Government Honest: Local Media's Role in Ensuring Government Accountability,(Jakarta:UNDPIndonesia, 2 009).

Robison,Richard\&VediR.Hadiz,ReorganisingPowe rinIndonesia:ThePoliticsof OligarchyinanAgeof

Markets,(London\&NewYork:RoutledgeCurzon,20 04).
Robison,Richard,Indonesia:TheRiseofCapital,(Jaka rta: Equinox,2008 [edisiperdana terbit 1986]).

Rogers,EverettM.,AHistoryofCommunicationStudy: ABiographicalApproach, (New York:Free Press,1994).

Siebert,Peterson, and Schramm,FourTheories ofthePress:TheAuthoritarian,

Libertarian,SocialResponsibility, andSoviet CommunistConceptsofWhatthe Press Should BeandDo,(Urbana:Universityof

IllinoisPress,1963).

Simpson,Christopher,ScienceofCoercion:Communi cationResearchandPsycological Warfare1945-

1960,(Oxford:OxfordUniversityPress,1994).

Siregar,Ashadi,"Perkembangan

MediaCetakLokal”,makalahdisampaikandalam seminarBeing

localinNationalContext:Understanding

LocalMedia andits Struggle,Surabaya,140ktober2002.

Sreberny,Annabelle,"TheGlobalandtheLocalin InternationalCommunications",M.G.

Sutrisno,PetrusSuryadi, “FenomenaKebangkitanIn dustriPersDaerah/MediaLokal”, Jurnal DewanPers,5(2011):77-90. 